\title{
Die Waarderende Ondersoek-aanpak as nuttige instrument vir verandering
}

\author{
Author: \\ Sophia van Helden \\ Affiliation: \\ Unit for Reformational \\ Theology, North-West \\ University, Potchefstroom \\ Campus, South Africa

\section{Correspondence to:} \\ Phia van Helden \\ Email: \\ phia@telkomsa.net \\ Postal address: \\ PO Box 16197, Lyttelton \\ 0140, South Africa

\section{Dates:} \\ Received: 13 Apr. 2014 \\ Accepted: 18 Aug. 2014 \\ Published: 09 Dec. 2014 \\ How to cite this article: \\ Van Helden, S., 2014, \\ 'Die Waarderende \\ Ondersoek-aanpak as \\ nuttige instrument vir \\ verandering', In die Skriflig \\ 48(1), Art. \#1831, 11 pages. \\ http://dx.doi.org/10.4102/ \\ ids.v48i1.1831

\section{Copyright:} \\ C 2014. The Authors. \\ Licensee: AOSIS \\ OpenJournals. This work is \\ licensed under the Creative \\ Commons Attribution \\ License.
}

Read online:
In hierdie artikel word Waarderende Ondersoek (WO) as 'n nuttige instrument vir verandering binne die kerklike praktyk bespreek asook die rede waarom dit as waardevol vir die kerk beskou word. Die verband tussen taal, denke en verandering word uiteengesit. Aangesien die huidige gereformeerde kerkpraktyk op skrifgefundeerde omkeer fokus, behoort gelowiges bewus te wees van effektiewe hulpmiddels wat tot diepgrondige verandering kan meewerk. Die spesifieke taalaanpak wat in verskeie dele van die Woord herkenbaar is, is grootliks binne die gereformeerde akademiese praktyk en ook binne die informele nie-akademiese teologiese praktyke onbekend. 'n Bespreking van die WO-aanpak, asook die historiese ontwikkeling, die navorsing wat op hierdie terrein gedoen is, 'n beoordeling van WO en 'n voorbeeld van die aanwending van $\mathrm{WO}$ wat op ' $\mathrm{n}$ informele wyse in die kerkpraktyk ter wille van verandering aangewend is, is daarom nodig.

This article discusses Appreciative Inquiry (AI) as useful tool for the sake of change within the church practice. AI as a language approach explains why it can be seen as valuable to the church. The relationship between language, thought and change are outlined. Since the current reformed church practice focuses on a scriptural turnaround, believers ought to be aware of effective aids working towards deep change. This language approach, which can be recognised in a variety of passages in the Word, is largely unknown within the reformed academic practice, but also within the informal non-academic theological practices. It is therefore necessary to discuss the AI approach, as well as the historical development, research done in this field, an assessment of AI and an example of where AI was informally utilised in a church practice for the sake of change.

\section{Inleiding}

Verandering binne die gereformeerde kerkpraktyk in Suid-Afrika kan daadwerklik plaasvind, maar dan behoort by die beginpunt begin te word, naamlik by denke. Om denke effektief en diepgrondig te verander, kan van Waarderende Ondersoek (WO) as taalinstrument gebruik gemaak word.

Denke word deur woorde (taal) uitgespreek. Taal as geformuleerde denke is die beginpunt van wilsbesluite wat op dade uitloop. Gelowiges se taalgebruik behoort daarom 'n fokuspunt te wees in 'n belangrike saak waar ernstige verdieping, bekering, omkeer of verandering aan die begin van die een-en-twintigste eeu ter sprake is (Acta 2012:509-5011; Du Toit 2000:46, 166; Hendriks 1999:17-19; Smit \& Vorster 2000:515, 529).

Volgens die gereformeerde tradisie bewerk die Gees verandering waardeur die bekeerling in oorgegewenheid veranderend leef: 'Bekeer U ons tot U, Here, dat ons bekeer kan wees' (Klaagl 5:21a; Heidelbergse Kategismus antwoord 8, 32a). Romeine 12:2 stel: '... laat God julle verander deur julle denke te vernuwe. Dan sal julle ook kan onderskei wat die wil van God is, wat vir Hom goed en aanneemlik en volmaak is'. Die gelowige is nie 'n willose pion nie; inteendeel, gelowiges behoort aktief mee te werk in denkverandering as die beginpunt van besluite en dade. Onwillekeurig kom die vraag na vore waarom gelowiges nie genoegsaam aandag aan woorde (taal) as die eerste instrument en as die hoofkanaal in hulle aktiwiteit gee om denke daadwerklik te verandering nie. Taal is immers die kanaal van dit wat in elkeen se denke aangaan (Strong 2007:107-110; Rom 10:14, 15; 12:2).

Gereformeerde gelowiges wat besef dat die eise van die een-en-twintigste eeu verdiepende denkverandering vra, vertoon grootliks 'n dualisme deurdat die beginpunt (denke deur taal) nié as belangrik en selfs noodsaaklik geag en gehanteer word nie (vgl. Schoeman \& Van der Berg 2011:1-7). Daar word egter vir gehoorsame omkeer en uitkomste gewens, gestreef en gebid, 
maar tog word die wense en strewes grootliks steeds op die ou manier ${ }^{1}$ gedoen. Nuwe uitkomste word in die vooruitsig gestel, maar die erns daarvan om by die beginpunt te begin, word vergeet of nagelaat.

Verandering, omkeer bekering, of verdieping kan nie agterstevoorom plaasvind nie. Dit beteken dat die gevestigde tradisionele I-denkwyse (institusionalistiese denke; Van Helden 2010:297-351) en gevolglik ook die I-taalgebruik die éérste saak behoort te wees wat aandag kry. Gelowiges gaan hoofsaaklik onbewustelik (Van Helden 2013a) met die gevestigde denkwyses voort (vgl. voetnoot 1 ), maar verwag ánder gevolge (vgl. Acta 2012:509-5011; Schoeman \& Van den Berg 2011:1-7). Daar behoort egter by die besef uitgekom te word dat verandering by die beginpunt - denke en taal behoort te begin en nie by die uitkomste nie. Roxburgh (1997:67) stel dat daar nie van vernuwing sprake kan wees indien daar nie 'n dieper, algehele en totale re-founding van denke (deur taal as pasmaat) plaasvind nie (vgl. ook Strong 2007:107-110).

Hierdie artikel fokus op WO as hulpmiddel en as instrument vir die gebruik binne gemeentes - gemeentes wat daarna streef om by die begin van verdieping en omkeer te begin. Aangesien WO in hierdie artikel hoofsaaklik as hulpmiddel vir informele gebruik aan geloofsgenote binne 'n nieakademiese ruimte bekend gestel word, word nie in hoofsaak op die formele akademiese benadering van WO gefokus nie. Volgens Branson (2004:19) is WO nie nét 'n metode nie, maar ook 'n proses en 'n gesindheid. Deur literatuurstudie, wat tot 'n groot mate die Sosiologiese Wetenskap insluit, én deur die informele aanbieding van die WO-aanpak op uitnodiging deur belangstellende gemeentes, word die volgende aspekte belangrik geag vir die verstaan van die Waarderende Ondersoek: wat Waarderende Ondersoek presies behels; Skrifgedeeltes wat met die taalaanpak verbandhou; die geskiedenis van WO en navorsing wat aan die hand van WO gedoen is; 'n saaklike evaluering van die WO-aanpak; en ten slotte die toeëiening van WO binne die tradisionele gereformeerde gemeentes. 'n Voorbeeld word gegee waar die proses in 'n gereformeerde gemeente aangewend is om denkverandering en uitkomste rakende 'n skriftuurlike omkeer te vergemaklik.

\footnotetext{
1.Daar is twee modelle waardeur verandering in ' $n$ gemeente bewerkstellig kan word, naamlik die liniêre en die chaordiese modelle. In die liniêre model is die problematiese situasie(s) duidelik geïdentifiseer en 'n breinstorm vind plaas om alternatiewe oplossings te vind. Na aanleiding van die daarstelling van alternatiewe, vind besluitneming plaas warna implementering geskied. Die liniêre lens om verandering te bewerkstellig, kan effektief wees indien die situasie(s) duidelik verandering te bewerkstellig, kan effektief wees indien die situasie(s) duidelik
aanduibaar is en indien daar meer as een oplossing voorgestel word. Die chaordiese lens is effektief wanneer diep vlakke van verandering noodsaaklik is. Daar word op hierdie lens besluit wanneer ' $n$ gemeente besef dat daar nie oppervlakkig oor ' $n$ saak besluit kan word nie en dat denkverandering bewerkstellig moet word sodat dit tot diepgrondige en effektiewe oplossings kan lei. Die problematiese situasie(s) is gewoonlik moeilik omskryfbaar en die wat, hoe, waar, wanneer en wie betrokke is, is nie altyd presies aanduibaar nie. Hierdie lens bewerk diep vlakke van veranderin deurdat met die besef van die erns van menslike pyn en kommer gewerk word sáám met die besef dat moontlikhede van diep verandering wel bestaan, maa dat niemand werklik weet hoe om dit te bewerkstellig nie. Die volgende stap in dat niemand werklik weet hoe om dit te bewerkstellig nie. Die volgende stap in hierdie donker situasie is om heeltemal uit die gemeentelike boxes (Gilbert 2004:55) uit weg te breek. Die gewilligheid hiertoe veroorsaak aanvanklik ' $n$ skynbaa onaantreklike terrein van onsekerhede. Wanneer daar faithfully binne hierdi stadium opgetree word, ontspring nuwe en kreatiewe maniere om diepgaande en effektiewe verandering daar te stel. Dit kan diep verandering meebring en nie net the simple outgrowth of older assumptions and patterns of congregational life' wees nie (Gilbert 2004:51-58).
}

\section{WO - 'n Waarderende taalaanpak}

WO as 'n waarderende taalaanpak kan deurgevoer word wanneer 'n betrokke saak of sake gewysig en verbeter wil word. In plaas daarvan om op die problematiese kant van die saak te fokus (vgl. voetnoot 1), word aan die hand van die WOaanpak eerder op dít wat reeds bestaan en as goed gereken word, gefokus; dít wat reeds geag of waardeer word in verband met die betrokke saak. Die proses begin dus deur dit wat rééds goed en prysenswaardig is waarderend te noem. Om op hierdie manier te praat, kom die gelowiges se dankbaarheid oor die betrokke saak na vore. Dankbaarheid is belangrik in gelowiges se lewe en verduidelik deels waarom die WO-aanpak so sterk by geloofsgemeenskappe aanklank vind (Branson 2004:43). Om in alles dankbaar te wees, is immers 'n wesenskenmerk van die gesindheid van getuigende gelowiges (1 Tes 5:18; vgl. Heidelbergse Kategismus antwoord 2c, 116).

Taal is die instrument wat die dankbaarheidsgesindheid onder die deelnemende gelowiges laat ontspring (Whitney 2010:77). Waarderende taal kan gesprekke onder gelowiges op só 'n manier laat ontwikkel dat die saak onder bespreking, ten goede ontwikkel (Niemandt 2013:163, 164). Dit is moontlik omdat taal denke rig (Branson 2004:43-64; Cooperrider \& Whitney 2005:2-5). WO as 'kreatiewe invalshoek ... help om die gesprek op dreef te kry ... dat'n luisterproses kan help om te onderskei ...' (waardeer; Niemandt 2007:69, 70, 111; vgl. ook Branson 2004:37-40; Cooperrider \& Whitney 2005:3-5, 7-10; Van Gelder 2009:112).

Die waarderende taalaanpak (WO) is volgens Chaffee (2005:7, 110 ) 'n bemoedigende en revitalising approach om verandering te bewerkstellig. Branson (2004:iv) beskryf dit soos volg: '... an understandable and doable model for attentive conversation, critical reflection and faithful envisioning'.

Chaffee (2005:7) brei hierop uit deur te noem dat gesprekke wat noukeurig volgens die WO-aanpak benader word, in werklikheid 'n bron van kennis is. Aan die hand van waarderende vrae word gesprekke gerig sodat die nodige kennis waarop weer voortgebou kan word, na vore kan kom. Deur die kennis wat tot die gesprekvoerders se denke toegevoeg word, word tot vernuwende insigte gegroei (denkverandering). Dit gaan dus oor die manier waarop gepraat en geluister word.

Waarderende taalgebruik, wat ook in die Skrif voorkom, is nie 'n nuutjie nie; dit is so oud soos die Skrif self (Branson 2004:ix-xiii; vgl. Skrifgedeeltes wat met WO verband hou). Hierdie verbintenis behoort vir gelowiges 'n gerusstellende en verkwikkende manier te wees om verandering op 'n natuurlike (organiese) manier te bevorder (Branson 2004:27). Die deelnemers spreek hulle deur middel van taal (Branson 2004:36) uit in verband met die saak onder bespreking, nadat noukeurig geformuleerde vrae oor die saak gestel is (Branson 2004:50; Cooperrider \& Whitney 2005:9). Wanneer WO in werking gestel word, skuif die tradisionele manier van probleemoplossing (deur op die negatiewe van die probleem te fokus) vanself op die agtergrond, aangesien waardering 
van die goeie (wat reeds binne die saak onder bespreking bestaan) die begin- en fokuspunt word (Cooperrider \& Whitney 2005:3). Deur waarderende taalgebruik ontluik gesprekke en word 'n gelade, kragtige kennispoel opgebou wat die deelnemendes se entoesiasme laat toeneem in die voortgang op soek na nuwe uitkomste (Branson 2004:22; Chaffee 2005:19, 20; Nel 2009; Whitney 2010:76).

Cooperrider en Whitney (2005:3-5, 7-10) beklemtoon die nut van taalgebruik wat van metafore, vertellings, wysheid- en kennistoevoegings en verbeelding gebruik maak. Cooperrider et al. (2008:3) omskryf WO (AI: Appreciative Inquiry) soos volg:

Appreciative Inquiry is the cooperative co-evolutionary search for the best in people, their organizations, and the world around them. It involves the discovery of what gives 'life' to a living system when it is most effective, alive and constructively capable in economic, ecological and human terms. AI involves the art and practice of asking questions that strengthen a system's capacity to apprehend, anticipate and heighten positive potential. The inquiry is mobilized through the crafting of the 'unconditional positive question' often involving hundreds or thousands of people. AI interventions focus on the speed of imagination and innovation instead of the negative, critical and spiralling diagnoses commonly used in organisations. The discovery, dream, design and destiny model links the energy of the positive core to changes never thought possible.

Die nut van die proses behoort gelowiges te bring by die hoe van omkeer. WO as beskikbare, maklik uitvoerbare en effektiewe taalinstrument bied aan enige gemeentelike groep die geleentheid om verdiepende groei en doeltreffende verandering te bewerkstellig deur die aanwending van die 4D-proses (English et al. 2003:81-83; vgl. ook Martin 2001:263, 265).

\section{Aanwending van die 4D-proses}

Die 4D-proses van Waarderende Ondersoek (WO) kan samevattend soos volg verduidelik word (Cooperrider et al. 2008:103-199; Cooperrider \& Whitney 2005:15-37): Die fasiliteerder of leier kry almal bymekaar wat hulleself tot die verbetering van die betrokke situasie(s) verbind het. Op sistematiese wyse stel hy dan die noukeurig geformuleerde en gefokusde vrae rakende die situasie(s) aan die groep. Deur die taalgebruik en die woordeskat word die deelnemers se gedagtes gerig en die gesprek begin deur te noem wat alreeds binne die betrokke situasie(s) goed en reg is.

Die eerste vraag lê klem op hoe elke deelnemer die beste spesiale oomblik binne die betrokke problematiese situasie(s) ervaar het en hoe die persone wat saam met die deelnemer tydens daardie spesiale oomblik teenwoordig was, dit ervaar het. Die tweede vraag fokus op 'n spesifieke geleentheid waar die deelnemers werklik geweet en ervaar het dat die situasie goed en reg was. Terselfdertyd word deelnemers gevra om op die scenario en die faktore asook wie die persone was wat die betrokke situasie(s) as goed en reg ervaar het, uit te brei.

Die antwoorde op bogenoemde vrae getuig van die gesprekvoerders se waardes na aanleiding van hulle goeie ervarings - die gelowiges se waardes binne die kerkpraktyk is immers op die Skrif gebou (vgl. 'WO as geestelike of spirituele proses').

Die taalaanpak is kommunikatief, met ander woorde twee tot drie persone beantwoord die vrae teenoor mekaar. Ter wille van korrekte terugvoering, kan die kern van elkeen se insette neergeskryf word. Die terugvoering vind mondelings plaas. Terwyl hierdie proses aan die gang is, word die kern van elkeen se gesprekspunt kripties deur die fasiliteerder of die leier opgeskryf vir almal om te kan sien, byvoorbeeld op 'n papier wat teen ' $n$ muur of ' $n$ bord opgesit is. Die inligting wat op hierdie waarderende manier ingewin word, word vervolgens breedweg gegroepeer om gedagtelyne of temas te vorm. Die gegroepeerde gedagtelyne vorm die punt(e) wat in die 4D-aktiwiteite hanteer word om tot meer insiggewende denke en nuwe uitkomste te ontwikkel (vgl. ook English et al. 2003:84, 85).

Gesprekvoering vorm die eerste stap van die 4D-proses, naamlik die Ontdek-aktiwiteit (Discovery). Die fasiliteerder of leier rig die deelnemers hierna om aan die volgende aktiwiteit deel te neem, naamlik die Droom-aktiwiteit (Dream). Dit fokus op die sake waarna ten diepste binne die besprekingspunt gestreef, gewens, gedroom of gebid word.

Die Ontwerp-aktiwiteit (Design) volg hierna. Hierdie stap kan op 'n ander tyd as die eerste twee stappe van die 4D-proses plaasvind, aangesien die eerste twee stappe tyd in beslag neem en energie verbruik. Die talle vernuwende insigte kan ook baat vind deur ryping wat tydsverloop bied. Tydens hierdie stap word planne gemaak wat van aksie, innovasie en kreatiwiteit spreek. Die vraag op hierdie punt in die proses is hoe die prentjie wat tot op daardie punt ontwikkel het, voortgesit kan word om 'n werklikheid te word. Dit kan strategies benader word en kort- en langtermyndoelstellings kan geformuleer word. Wat veral op hierdie stadium van belang is, is om die proses deur te voer. Volhoubare toegewydheid deur deelnemers is hiervoor nodig.

Laastens volg die Bestemmingsaktiwiteit (Destiny). Tydens hierdie fase word dit wat ontwerp is, deurgevoer en 'n werklikheid gemaak (vgl. Whitney 2010:76, 77, 83). Van die begin tot die einde van die proses rig taal die denke om na die beste moontlikhede te bly soek wat lig binne die betrokke situasie(s) kan bring. Binne die $4 \mathrm{D}$-taalproses is refleksie na afloop van die Bestemmingsaktiwiteit van groot belang. Sodoende word dit aangetoon en verseker dat effektiewe verandering en groei wel in verband met die betrokke situasie(s) plaasgevind het (vgl. Martin 2001:269).

\section{Skrifgedeeltes wat met WO verband hou Lig verdryf donkerte}

Vanuit die gereformeerde tradisie word gelowiges se dade pneumatologies beskou: God begin en bewerk byvoorbeeld verandering in sy kinders sodat hulle weer in staat is om 
verandering te kan bewerkstellig. Romeine 12:2, asook 2 Korintiërs 3:18 en Matteus 7:7 en 8 stel die verhouding tussen God se dade en die gelowiges se dade in perspektief.

Gelowiges wat verdiepende verandering najaag, se strewe kan ten diepste as die navolging van Psalm 139:11, 12 en Johannes 3:21 beskryf word. Hier handel dit oor God wat lig in elke donker omstandigheid kan bring (Chaffee 2005:9). Gestagneerde denke in 'n status quo-ekklesiologie wat om diepgrondige omkeer en vernuwing roep (Schoeman \& Van den Berg 2011:1; Van Helden 2010:353), is 'n aktuele voorbeeld van 'n problematiese situasie; 'n donker toestand wat om denkverandering roep. 'n Verdere voorbeeld van 'n donker toestand is die krimpende tradisionele gereformeerde kerkverbande wat reeds die pad van 'slow death' (Gilbert 2004; Van Helden 2010) betree het en wat om ernstige en diepgrondige verandering roep. Die krisis van krimpende gereformeerde kerke het onder andere aanleiding gegee tot die 2012-GKSA-Sinodebesluit wat ten gunste van ' $n$ daadwerklike omkeerstrategie geneem is (Acta 2012:509-5011). Die WO-aanpak wat verfrissende en liggewende moontlikhede binne só 'n donker situasie in gemeentes kan bewerkstellig, word deur Chaffee (2005:9) as die DNA (beginsels) van WO genoem. WO-beginsels word gespesifiseer soos dit in Filippense 4:8 verwoord word:

... alles wat waar is, alles wat edel is, alles wat reg is, alles wat rein is, alles wat mooi is, alles wat prysenswaardig is - watter deug of lofwaardige saak daar ook mag wees - daarop moet julle julle gedagtes rig. (vgl. Rom 12:1, 2; Niemandt 2007:69, 70)

Die WO-aanpak is hiervolgens ' $n$ ligbewerkende hulpmiddel en instrument om donker situasies te benader en wat meewerk om dit te verbeter (Ps 139; Joh 10:10; Branson 2004:44; Chaffee 2005:9). Wanneer denke as beginpunt van verdieping en verandering binne 'n ekklesiologiese donker situasie ter sprake is, openbaar dit die gelowiges se strewe om 'in $\mathrm{u}$ lig die lig te sien' (te soek en te vind) (Ps 36:10 Mat 7:8 OV). Die gesamentlike gesindheid om in samewerking met mekaar elkeen se gedagtes 'op die goeie en prysenswaardige' te rig, vertoon die eenheid in soeke wat deur die liefdesgebod gedryf word (Van Helden 2014:4-6); die onderlinge liefde is derhalwe 'n beginsel agter die WOaanpak: 'Ek gee julle 'n nuwe gebod: julle moet mekaar liefhê. Soos Ek julle liefhet, moet julle mekaar ook liefhê' (Joh 13:34).

Die WO-taalaanpak wat binne 'n gemeentelike opset aangewend word, vertoon die strewe na lig en waarheid, aangesien die gelowige se nuwe natuur (in Christus), liefdesgedrewe verhoudings en effektiewe organisering prakties wil uitleef (Whitney 2010:74-76). Deelnemende gemeentelede - individueel en kollektief - gee hulle beste bydraes in hulle gesprekke (taal) rondom die donker situasie onder bespreking. Die opbouende inligting wat elkeen gee, fokus nie hoofsaaklik op die negatiewe in die situasie nie, maar wel op dit wat reeds bestaan en wat reg en goed is en waarop ter wille van verandering gebou kan word.
Omdat alle mense, ook gelowiges, sosiaal funksioneer, vorm die gemeentelike gesprekvoerders 'n bron van onbeperkte verhoudings en kennis soos dit in elke unieke gemeente deur God voorberei en daargestel is (2 Kor 5:5). As die beeld van God kan gelowiges hulle kennis en ervaringskatte in vryheid (Cooperrider et al. 2008:26-30; Chaffee 2005:7) tot voordeel van die gemeente aanbied en deel. Dit gebeur deurdat almal die geleentheid kry om hulle unieke gedagtes op die gestelde vrae te formuleer en uit te spreek. In die loop van die gelowiges se lewe is immers baie geleer en beleef wat as goed en nuttig gereken kan word en wat vir die gemeente van waarde kan wees ten opsigte van die betrokke donker saak onder bespreking (vgl. 2 Kor 3:18; 2 Kor 5:17-21).

\section{Drie-eenheid}

Wanneer die gewaardeerde kennis deur die gesprekvoerders geformuleer is, werp dit lig op die situasie onder bespreking en rig hulle tot nuwe insigte (denke) wat binne die raamwerk van die WO (vgl. 4-D-proses), tot verbetering van die situasie kan ontwikkel. Die onderlinge gesprekvoering deur die deelnemende gelowiges vind aldus Magnusson (2012:46-48) ten diepste begronding in die Drie-eenheid: God drie-enig is volkome een in liefde, een in die onderlinge verhouding met mekaar en een in samewerking met mekaar; in geen handeling tree een van die Persone op sonder die ander nie. Magnusson (2012) stel dat:

the devine will and activity originate in the Father, are actualized by the Son and are perfected by the Holy Spirit ... Not only does God reach out to humanity and the world, but God also encircles the world .... (p. 48)

Gelowiges kry die ruimte om in liefdevolle eenheid binne 'n eendragtige kommunikatiewe verhouding met mekaar saam te werk ter wille van die koninkryk. As die beeld van God verkeer gelowiges derhalwe in verhoudings 'to participate ... in the lives of one another' (Magnusson 2012:49). Tydens die WO-proses manifesteer die gemeenskap van gelowiges daadwerklik deurdat hulle hulself aan God gee en 'all other persons as far as is possible and a receiving of theirs in return. This perichoresis of love is the created likeness and manifestation of the Holy Trinity' (Magnusson 2012:49).

\section{WO as geestelike of spirituele proses}

Binne 'n gemeente is die gelowiges se gesprekke tydens die WO-proses sprekend van die waardesen waarheidsaansprake wat in Christus (die Woord) gegrondves is. Hy is die Weg en die Waarheid en die Lewe (Joh 14:6; Cameron et al. 2010:17-31). Waarheid en lig is in Jesus Christus as Persoon beliggaam. Deurdat die gelowiges kommunikatief (woorde) waarderend soek na dit wat vir Hom aanneemlik, reg en goed is, is die Ligbewerker (Christus, die Woord) self teenwoordig waar twee of meer in sy Naam byeen is. ' $n$ Geestelike of spirituele ervaring word prakties beleef wanneer die beginsels wat in Filippense 4:8 geleë is tussen die deelnemende medegelowiges geleef word. Die waarheid wat deur hierdie gesprekke na vore kom 'is thruth 
to be grasped through the practice of the Christian life' (Cameron et al. 2010:17).

Wanneer oor die moontlikhede binne die situasie gedroom en gebid word, word die mooie, die prysenswaardige, deugdevolle en dit wat goed is, voorop gestel. Wanneer gesamentlik op hierdie manier gepraat word, kom dít wat deur die jare deur die gelowiges in die 'practice of the Christian life' geleer en ervaar is, as 'n motiverende krag na vore. In die gewone lewenspraktyk waar die donker saak ter sprake is, spruit die gelowige se krag uit die groot positiewe krag van Christus as die lewende Woord (Strong 2007:99; Van Helden 2010:375). Binne hierdie 'spiritual sensibility' (Whitney 2010:77) is die probleem (donker saak) nie meer die fokuspunt nie. Die fokus het deur die taalaanpak geskuif na dít waarna gestreef word. Dit lei tot die ontstaan van 'n sterk betrokkenheidsproses wat organies voortstu.

Whitney (2010:74) se navorsing toon aan waarom WO as taalinstrument so nuttig is - veral binne groepe gelowiges. Saam skep die deelnemende gelowiges 'n gemeenskaplike ruimte waarbinne dankbaarheid, waardering, dryfkrag en verandering beleef word (Whitney 2010:85). In die gemeenskaplike ruimte word geestelikheid of spiritualiteit ervaar. Dit word verder bewerkstellig deurdat die gelowiges eenheid in taalgebruik (woordeskat) beleef wanneer energiegewende betrokkenheid ervaar word en 'n onderlinge gemeenskaplike bewussyn, gegrond op Skrifkennis en Skrifwaardes, daargestel word.

\section{Soeke vanuit skrifgedrewe waardes}

Die Skrif is die riglyn vir gelowiges (Van Helden 2010:300) se optrede. Skrifkennis en -waardes vorm die gemene deler tussen die gelowiges. Hulle ken byvoorbeeld die Groot Opdrag en weet dat hulle hieraan gehoorsaam behoort te wees (Chaffee 2005:4; Van Helden 2010:331-334). Gedagtes voortspruitend uit skrifgedrewe opdragte, voorskrifte en beginsels en die strewe om dit in die praktyk waar te maak, word altyd deur taal verwoord. Tydens sodanige gesprekke word die kennispoel deur rasionele, geestelike (spirituele) en intuïtiewe aspekte gevul (Chaffee 2005:7; Whitney 2010:84, 85).

Die geformuleerde waardes weerspieël die kern van dankbaarheid en positiewe krag (vgl. 1 Tess 1:2, 3; Branson 2004:xi, 40,43-58). Terselfdertyd ervaar elkeen betrokkenheid, waardering en erkenning. Deur die gesamentlike soeke (vgl. Matt 7:7; Chaffee 2005:13) word wysheid gedeel, vertroue geskep en meer as net 'n gevoel van samewerking word bewerkstellig. Dit gebeur omdat elkeen sy diepste hartsbegeertes in verband met die goeie en aanneemlike (lig; Skrif) met betrekking tot die betrokke donker situasie uitspreek. 'n Waardegedrewe lewenspraktyk van gelowiges is derhalwe 'n teologiese saak.

Die betrokkenheid van gelowiges met 'n gemeenskaplike waardestelsel (lg. kom deur middel van 'n deelnemende taalproses as rigtinggewende instrument na vore) benadruk die feit dat taal (uitsprake) 'n integrale deel van teologie in die praktyk is (Wepener 2005:112). Wepener (2005) meld die volgende:

God is actively working in the world, and is not only an afterthought to explain what is happening in the world ... the description of what is happening in the world is a theological task. (p. 11)

Die lewende Christelike praktyk vorm die inhoud vir die taalaanpak, aangesien deelnemende gelowiges hulle diepste waardes verwoord en met mekaar deel; waardes wat in hulle harte bewaar en gekoester word (vgl. Luk 2:19, 51; Cameron et al. 2010:52). Die lewenspraktyk, as teologiese saak, word deur die WO-proses waarneembaar wanneer eerlike gesprekke gesamentlik as betekenisvol ervaar word. Spirituele resonansie word daargestel en 'n ons-belewenig in plaas van $e k$, hulle of julle ontstaan binne hierdie goeie en aangename klimaat met die doel om ten goede te verander (Branson 2004:22; Nel 2009; Niemandt 2013:163, 164).

\section{Gewillig en bekwaam in die nuwe lewe in Christus}

Volgens Whitney (2010:76) bewerk die klimaat wat die WO-taalproses vir die een-en-twintigste-eeuse gelowige daarstel, 'n mate van epifanie. Whitney (2010:78-82) meen dit is ook deels die rede waarom die taalaanpak as geestelik of spiritueel ervaar word. Die belewenis van WOas taalinstrument is 'life-affirming, good, true and beautiful' (Whitney 2010:83). Dit bewerkstellig 'a life-enhancing dynamic' (Whitney 2010:85) wat denke rig om liggewend te wees (vgl. Branson 2004:43-64; Cooperrider \& Whitney 2005:2-5; Van Gelder 2009:112). Spontane taalgebruik wat tot liggewende veranderings lei, toon dat die gelowiges gewillig en bekwaam is (Fil 2:13) om die nuwe lewe in Christus in die lewenspraktyk uit te leef.

\section{wO word herontdek}

Soos vroeër gestel, is die doel van hierdie artikel hoofsaaklik om WO aan teologiese nie-akademici bekend te stel; dit gaan dus nie net oor die metode wat akademici sou volg nie, maar veral oor die informele deelnemende proses van geloofsgroepe, die aanpak en die gesindheid daarvan (Branson 2004:19; Martin 2001:261-267). Vir akademici wat aan tradisionele metodologieë gewoond is, is die WO as deelnemende waarneming van die werklikheid grootliks onbekend (Cameron et al. 2010:34-37; Schoeman \& Van den Berg 2011:1-4; Wepener 2005:116-124). Vir baie gelowiges mag die WO-aanpak ook na iets nuuts klink, maar in werklikheid is die manier waarop taal gebruik word, nie onlangs deur iemand uitgedink nie.

\section{Branson (2004) stel die volgende:}

Mark demonstrates the appropriateness and the power of this approach by lifting up the central place of the positive thanksgiving and gratitude - within scripture. (p. xi)

In die Skrif begin Paulus sy briewe deurgaans met dankbetuigings oor goeie sake voordat enige ander saak ter 
sprake kom (bv. 1 Tess 1:2). Branson (2004:43-64) verwys verder ook na die sewe briewe in Openbaring waar die skrywer, Johannes, na aanleiding van die openbaring deur Jesus op Patmos, eers op die goeie sake in die gemeentes fokus (Op 2:19). Tog word die negatiewe sake nie uitgelaat nie; deur die wyse van benadering word die gelowige egter na dit wat prysenswaardig en goed is in die oë van die Here gelei (vgl. ook Chaffee 2005:2, 10).

Die evangelieskrywers Matteus $(5: 14,15)$ en Lukas (18:35-43) verwoord sekere van Jesus se optredes sodanig dat die woorde (taal) die aangesprokene waarderend rig, begelei en by dit uitbring wat vir God aanneemlik is. Die noukeurige vraag as die beginpunt om denke gefokus te rig, word só gestel dat 'n vernuwende, liggewende gevolg bereik kan word (vgl. Mark 5:9; 5:31; 8:27; Luk 18:35-43; McLaren 2006:49).

Uitbreidend op hierdie voorbeelde is dit interessant om die volgende eerste voorbeeld in die Skrif kortliks te noem: God het geskep en dit was baie goed (Gen 1:31). Na die negatiewe vraagstelling deur die Satan (Gen 3:1, 4), het die mens negatiewe kennis en denke verkry (Gen 3:4-6). Deur van die kennis van goed én kwaad bewus te word (Gen 2:9; 3:6, 11), het die mens die vermoë gekry om keuses (te waardeer en te onderskei) uit te oefen en sy denke te rig of te verander. Deur vraagstelling soek God vir Adam en Eva eerste op (Gen 3:8) en bring self eers die moontlikheid van hoop deur 'n verbeterende gevolg van die sonde te gee, naamlik die moederbelofte (Gen 3:15).

Deur hierdie enkele voorbeelde word aangetoon dat waarderende taal kennis deur vraagstelling na vore bring kennis wat deur die lewe opgedoen is en deel van elke man en vrou is. Op hierdie manier word iets nuuts by mekaar geleer, gedagtes groei en verandering in denke kan bewerkstellig word (vgl. ook Joh 4:5-26; Mark 6:37-44; 8:27-30; 12:16, 17 en ook die gelykenisse). Niemandt (2007) verwoord vraagstelling as taalinstrument soos volg:

Waarderende ondersoek is 'n proses van geestelike onderskeiding wat mense vorm deur die regte vrae te stel. (bl. 70)

Indien die gelowige gesprekvoerders hierdie aanpak volhou in sake waar verandering nodig is, kan ' $n$ Christosentriese denkwyse in beweging kom waarbinne die Gees saam met Christus herskeppend in die gelowiges kan werk (Branson 2004:ix-xii). Die gelowige word inderdaad in die Skrif aangeraai om 'n stomp byl te slyp (Pred 10:10; vgl. Branson 2004:xiii); gelowiges moet dus gedryf word om die wilsbesluit te neem om self iets te doen wanneer 'n situasie nie meer doeltreffend is nie. Vir gelowiges behoort die WO-aanpak bloot 'n herontdekking te wees van 'n manier waardeur die lig en waarheid, maar ook dankbaarheid, maklik na vore kom (Chaffee 2005:10).

\section{Geskiedenis van die Waarderende Ondersoek}

Teologie was tot en met die tweede helfte van die vorige eeu 'n outonome studieterrein wat onaangeraak tussen ander navorsingsterreine gestaan het. Nuwe metodologieë het sedertdien ontwikkel sodat Teologie se posisie verskuif het en vandag deel van die sosiale samelewingsverskynsel uitmaak (De Wet 2006:57-87). Praktiese Teologie vorm deel van hierdie verskuiwing. Alhoewel Praktiese Teologie aan die begin van die een-en-twintigste eeu ' $n$ relatief jong dissipline is, vertoon dit baie sterk as aktuele dissipline (Heitink 1999:155; Pieterse 1993:2, 51; Pieterse 2010:8; Van Gelder 2009).

Praktiese Teologie as aktuele dissipline is daardie deel van Teologie wat krities oor die aksies van gelowiges en hoe God deur sy Woord in hulle lewens gestalte kry, nadink (Heyns \& Pieterse 1990:1). Praktiese Teologie is egter nie net binne akademiese kringe tuis nie (Cameron et al. 2010:7982), maar vertoon sy aard, naamlik teologie in die praktyk, toenemend by die gewone gelowige in hulle alledaagse godsdienstige en problematiese omstandighede (Branson 2004:ix; Burger 1999:19, 20; Martin 2001:261-275; Retief 2009:iv-26).

\section{Aksie Navorsing as voorloper van die Waarderende Ondersoek}

Na die Tweede Wêreldoorlog het daar in die noordelike industriële demokratiese gebiede 'n ondersoekmetode ontstaan wat verbeterende verandering as uitkoms bewerkstellig het. Dit het tot die ontwikkeling van Aksie Navorsing gelei. Hierdie metode van navorsing was 'more like a social movement than an academic field ... within and across many academic disciplines' (Cameron et al. 2010:39). Aksie Navorsing het sedert daardie jare gegroei en fokus in die huidige tyd grootliks op interpersoonlike verhoudings, effektiewe leierskap, administrasie, groepsdinamika en georganiseerde kulture (Allen 2007).

Die moontlikhede wat Aksie Navorsing ter wille van verandering ingehou het, het gou groot suksesse binne professionele praktyke soos gesondheid en onderwys gehad (Cameron et al. 2010:40). Dit het egter nie daar geëindig nie aangesien die openbare sektore, waaronder kerke en geloofsgebaseerde groepe, ook die voordeel van hierdie benadering ingesien en begin toepas het (ibid:41). Teologiese Aksie Navorsing (TAR = Theological Action Research) het hierdeur die lig gesien (ibid:47-51, 64).

TAR bied 'n metodologiese en teologiese aanpak wat aan die ontwikkeling van teologie vir geloofspraktyke toegewy is (Cameron et al. 2010:5). Praktiese Teologie en Aksie Navorsing is deur TAR by mekaar gebring en deur hierdie verbintenis het 'n nuwe manier van dink na vore gekom (ibid:79-82). Kruisbestuiwing vanuit ander dissiplines, ten spyte van vroeëre akademiese vooroordele en kompartementering (ibid:7-13. 58; vgl. 'Navorsing aan die hand van $\mathrm{WO}^{\prime}$ ), het stelselmatig meegewerk dat die sosiologie van godsdiens in die navorsing ingebring is (ibid:32, 41-45, 47, 82) deurdat 'n nuwe manier van dink na vore gekom het oor gesprekke aan die hand van teologiese refleksie (ibid:47). 
Buiten Praktiese Teologie, word Aksie Navorsing ook met baie ander terreine verbind, byvoorbeeld landboukundige ontwikkeling (Chambers 1997), tegnologiese ontwikkeling (Greenwood \& Levin 1998:33), opvoedkundige hervorming (Darling-Hammond \& Snyder 2000), omgewingsbeheer (Motteux et al. 1999), openbare gesondheid (Greenwood \& Levin 1998: 20), inligtingsisteme (Champion \& Stowell 2003), organisatoriese verandering en ontwikkeling (Retief 2009:44; Greenwood \& Levin 1998:69), bestuurswese (Whitney et al. 2004), asook wetenskappe rakende antropologie, gedrag, medisyne, psigologie, sport en kwantum fisika (Chaffee 2005:8).

Aksie Navorsing word verder deur 'n verskeidenheid maniere van uitvoering of aanpak bewerkstellig. Om slegs 'n paar te noem: Deelnemende Aksie Navorsing (PAR; Wepener 2005:111-118; Whyte 1991), Deelnemende Landelike Waardering (Chambers 1997), Aksie Wetenskap en Aksie Leer (Reason 1994:49; Whyte 1991), Storieluister (Magnusson 2012) en WO (Branson 2004:1-156; Cooperrider et al. 2008).

Volgens Cooperrider et al. (2008:3) en Dick (1997) is die aard van WO uitnodigend om in die menslike en organisatoriese velde verandering ten goede te bewerkstellig. Hierdie aanpak het by Case Western Reserve University in die tagtigerjare van die vorige eeu begin en as 'n spiritueelbegronde metode, proses en gesindheid (Branson 2004:19) vinnige groei beleef en wêreldwyd gevestig geraak (vgl. Cameron et al. 2010:512). Teen 1999 was veral Cooperrider as die vestiger van hierdie aanpak bekend (Branson 2004:xiv; English et al. 2003:80, 81).

Die WO-aanpak het algaande so in gebruik toegeneem, dat gelowige gemeenskappe wat méér met WO vertroud is, dit as 'n uiters nuttige hulpmiddel ter wille van goeie verandering beskou: '... the remarkable gift appreciative inquiry represents for any community of faith and practice' (Chaffee 2005:20).

\section{Navorsing aan die hand van Waarderende Ondersoek}

Die navorsers wat WO wêreldwyd gevestig het (Cameron et al. 2010:7-11; Whitney 2010:73), is te veel om op te noem (onder andere Chaffee, Cooperrider, English, Stavros, Whitney, Trosten-Bloom, Cherney, Fry, Branson, Reason). Waarderende Ondersoek as metode, proses en ook as gesindheid (Branson 2004:19) het aan talle persone wat binne 'n gegewe situasie verbeterende verandering op 'n formele én 'n informele wyse wou bewerkstellig die geleentheid daarvoor gebied.

Die verrassende van die WO-aanpak is egter dat dit nie eksklusief 'n metode vir akademiese doeleindes is nie (Brydon-Miller et al. 2003:21; English et al. 2003:71-86). Die aanpak is sodanig dat nie-akademiese persone en groepe, byvoorbeeld predikante, fasiliteerders en groepleiers, dit met groot vrug op 'n informele wyse binne hulle eiesoortige konteks kan gebruik. Retief (2009:44) stel dat die WO-proses veral in Suid-Afrika die potensiaal het om diepgaande verandering te bewerkstellig. Hy voeg egter by dat dit nog nie werklik in die groter Suid-Afrikaanse gemeentelike konteks gebruik word of erkenning geniet nie:

This observation had been confirmed by the puzzled reaction of pastors when the topic of this research study had been discussed with them. This study therefore intended to make a contribution towards the church community in terms of its ability to successfully manage change.

Retief (2009:54) het'n studie oor organisatoriese ontwikkeling gedoen, waartydens die WO-proses met groot vrug binne 'n gemeente aangewend is. Retief se navorsing is derhalwe nie 'n teologiese studie nie. Afrikaanse teoloë soos Niemandt (2007:68) en Nel (2009; vgl. ook Schoeman \& Van den Berg 2011:1-7), meld ook spesifiek die bruikbaarheid van WO 'as kreatiewe invalshoek' (Niemandt 2007:69). Nel (2009) benadruk die waarde van WO vir gemeentebou, onder andere aan die hand van Woolever en Bruce se navorsing. Wat die proses so aantreklik maak, is die feit dat enige groep, hetsy individue, die leierskorps of die gemeente (kollektief), WO kan gebruik om enige donker situasie te bespreek. Dit sluit letterlik enige situasie in, byvoorbeeld aspekte van die liturgie, dissipelskap, evangelisasie, gemeenskap van gelowiges, of wat ook al aandag behoort te kry (English et al. 2003:71-77; Magnusson 2012:22-26; Martin 2001:261-275; Schoeman \& Van den Berg 2011:1-7; Wepener 2005:111). Schoeman en Van den Berg (2011:1) se navorsing beklemtoon ook dat 'n waarderende aanpak vir kerkdoeleindes uitgeknip is.

Die grootste doring in die vlees wat reeds teen die einde van die vorige eeu druk bespreek is (Smith 1983:296-302,310), was die geneigdheid dat die sosiale en teologiese wetenskappe wedersydse ondersoeke grootliks beperk het. Die rede hiervoor was dat die siening destyds gehuldig was dat die Sosiale Wetenskappe die sekulêre lewe nagevors het, terwyl die Teologie die sakrale lewe nagevors het (Smith 1983:301; vgl. ook Morris 1983:310, 311; Smith 1983, 1984). Wepener (2005:111-118) argumenteer teen die vroeëre siening van kompartementering, deur te stel dat God deurentyd aktief in die wêreld werksaam is; daarom is enigiets wat in die wêreld aangaan, 'n teologiese saak.

Ganzevoort (2006:151) oorspan ook hierdie dualisme en beklemtoon 'de geleefde religie in al haar verschijningsvormen ... met het oog op onderling verstaan en beter samenleven'. Osmer (2008) brei soos volg uit oor die samelewing:

(Practical) theology must face up to the challenges of a postmodern context characterized by a high degree of pluralism, fragmentation, and scepticism ... It must find new ways of developing truth claims and values that will be persuasive to a sceptical postmodern world. (p. 154)

Die gebruik van 'n instrument soos Deelnemende Aksie Navorsing en WO as onderafdelings van Aksie Navorsing, is volgens die perspektief van onder andere Wepener, Ganzevoort en Osmer, 'n integrale saak van teologie, in die besonder van Praktiese Teologie. 


\section{Evaluering van Waarderende Ondersoek}

Volgens Chaffee (2005:4, 5) behoort die moontlikhede wat in die WO-aanpak opgesluit is, nooit as 'n eenmalige kitsoplossing, 'n wondersalfie, 'n doen-dit-selfproses of 'n nuutjie ter wille van verandering beskou te word nie. Wat WO wel bied, is ' $n$ gesonde raamwerk vir leer en verstaan (ibid:8). Hierdeur word beter onderlinge verhoudings ontwikkel, terwyl sinvolheid (lig) binne die betrokke situasie beleef word. Chaffee is ook van mening dat WO in die algemeen die individu in die proses verryk, terwyl 'n gesamentlike belewing van vryheid, vreugde, hoop, vertroue en 'revitalising' (ibid:4, 5) tot stand kom.

\section{Voordele van Waarderende Ondersoek}

Die voordeel van WO binne geloofsgemeenskappe is dat die konteks en die waardes reeds deel van die gemeente is (Martin 2001:264; vgl.' WO as geestelike of spirituele proses'). Gemeenskaplike waardes hoef dus nie eers deur 'n eksterne proses ontdek te word nie. Gelowiges noem in die waarderende aanpak dié dinge wat hulle werklik méér binne die betrokke situasie wil sien, waarvoor hulle staan en waarop hulle hoop (Whitney 2010:86); dinge wat vir hulle belangrik is en waaroor die gelowiges werklik dankbaar is. WO fokus derhalwe op wat kan wees (English et al. 2003:86-88), naamlik 'n doelgerigte proses om die hoop wat in die gelowiges leef, 'n werklikheid te maak. Daarby is WO 'n bemagtigende, werkbare taalaanpak waardeur op klein of groot skaal meer van dit wat reeds bestaan of wat reeds bereik is, geleer kan word (Whitney 2010:73, 86).

Chaffee (2005:7) meen dat hierdie manier van bemagtiging en leer nie onderskat moet word nie (vgl. ook Wepener 2005:116); dit kan eerder as 'n geskenk vir geloofsgemeenskappe gesien word. Omdat die proses nie met objektiewe, abstrakte konsepte besig is nie, maar met taal, leer, verhoudings en lewende sisteme, word tydens die gesprekke diepgaande sin van die betrokke saak gemaak.

Deur op gelowiges se strewes, kennis- en ervaringskatte te fokus, word op 'n baie energieke en kreatiewe wyse deur talle moontlikhede voortbeweeg tot die daarstelling van 'n veranderde uitkoms. Geloofsgemeenskappe baat grootliks by hierdie aanpak (Martin 2001:263-275): algemene kennis en die insluitende, eenvoudige proses is vir kerklui bruikbaar, aangesien hulle nie noodwendig vertroud is met, of enigsins belang stel in 'n akademiese aanpak nie. Gemeentes kan hierdie aanpak binne hulle eie unieke situasies aanwend, hulle eie vrae opstel, dit binne hulle eie tyd en ruimte deurwerk en binne hulle eie konteks self by oplossings uitkom.

Aangesien 'n groot aantal persone gelyktydig oor hulle waardes en wense gesprek kan voer (Whitney 2010:76), word op ' $n$ informele wyse op die beste in elke deelnemer gefokus. Die proses laat die deelnemendes toe om eenheid, asook die verskeidenheid wat aangebied word, te ervaar. Onderling word van elkeen se kennis én beperkings ten opsigte van die betrokke situasie(s) geleer en die gesprek word sodanig gerig dat dit in die bevestigende vorm gevoer word (Whitney 2010:86). Dit beteken dat die gesprekke oor dit wat goed en reg is binne die betrokke situasie handel en nie oor dit wat verkeerd, negatief of sleg is nie. Die taalgebruik getuig en bevestig derhalwe aspekte wat reg, goed en positief is. Hierdie raamwerk voorkom negatiwisme, elitisme en egosentrisme. Die uitstaande en verrassende gebeure tydens WO is die geweldige krag wat binne die groep na vore kom (Chaffee 2005:7; Cooperrider et al. 2008:26-30; English et al. 2003:80). Krag en verdiepte onderlinge verhoudings word ontsluit deurdat gefokus word op dit wat die deelnemers na aan die hart lê.

Alhoewel die aard van die proses verrykend is, word die menslike gebrokenheid, swakheid, onvolmaaktheid en probleme nie uitgesluit of geïgnoreer nie. Aangesien die taalaanpak dit wat goed, reg en prysenswaardig is na vore bring, word organies wegbeweeg van dit wat nie opbouend is nie en voortgestu na 'n verhelderende en gesonde nuwe terrein (Chaffee 2005:8, 9; Cooperrider et al. 2008:4; English et al. 2003:87; Whitney 2010:73).

Soos Cooperrider, Whitney en andere, meen Retief (2009:44) ook dat WO ter wille van verandering, groot potensiaal het en opwindende nuwe moontlikhede kan inhou. Die WO-proses word as uitnodigend beleef om ' $n$ positiewe omwenteling ter wille van verandering in enige groepering of bestuur daar te stel en ' $n$ waarderende kultuur te laat ontwikkel (Whitney 2010:73, 84).

Leierskap word grootliks deur die WO-aanpak geraak. Volgens die Skrif is dit die taak van leiers om mense so te rig dat hulle self tot skrifgefundeerde oplossings kan kom (Gilbert 2004:12-38, 43). Leierskap wat op beheer gerig is, verander na waarderende deelnemende leierskap; meganistiese modelle draai na aktiewe selforganisering; en ' $n$ afwaartse spiraal van negatiwiteit rondom 'n betrokke donker probleem, spiraal opwaarts in 'n verrykende, waarderende, energieke proses (Whitney 2010:86). Die betrokke problematiese saak word nie van 'buite' (Moore 2008:216) onder leiding van net één persoon ('n outoritêre, nié-deelnemende navorser) bestuur nie (Martin 2001:272). Daar word wel binne groepsverband waarderend deelgeneem om vas te stel wat reeds goed is en om dan saam daarvandaan vorentoe te beweeg sodat effektiewe oplossings vir die betrokke saak daargestel kan word.

WO is vir die betrokkenes ' $n$ manier van dink - dink binne ' $n$ raamwerk. Dit is 'n holistiese benadering deur te waardeer en te kies van dit wat reeds as goed en mooi bestaan (English et al. 2003:87, 88 vgl. ook Schoeman \& Van den Berg 2011:6).

\section{Nadele van Waarderende Ondersoek}

Die grootste nadeel binne die konteks van hierdie artikel is dat die voordeel van WO vir Suid-Afrikaanse gelowiges en godsdienstige leiers onbekend is. Binne akademiese kringe het Smith reeds in 1983 geskryf dat kompartementering en vooroordeel nadelig vir die uitbreiding van WO was (vgl. 
'Navorsing aan die hand van $\mathrm{WO}^{\prime}$ ). Die feit dat hierdie nadeel vanuit die akademie gekom het, kan vandag steeds 'n afskrikmiddel wees vir diegene wat nie met die WO-proses bekend is nie, aangesien die persepsie maklik kan ontstaan dat 'n donker situasie akademies benader móét word (vgl. ook English et al. 2003:82, 83).

Schoeman en Van den Berg (2011) stel in hulle resente artikel die volgende:

Dalk is die tyd ryp om juis nóú, vanuit 'n ander hoek, na nuwe antwoorde en strategieë te soek en in dié proses nie net 'n bydrae te bied tot ' $n$ bepaalde positiewe gemeentelike ontwikkeling nie, maar ook verrykende pastorale perspektiewe aan die persone betrokke te bied. Die doel van die artikel is om waarderende en positiewe aspekte in dié verband te ontgin.(bl. 1,2)

Vir die handjievol gelowiges wat moontlik wel van die voordele van die WO-aanpak bewus is, is vrees vir die onbekende en die ongeoefende manier van dink en doen, tesame met ' $n$ gebrek aan vertroue en die moeite om ander aangaande die proses te oortuig, skynbare struikelblokke om te oorkom. Weens onervarenheid en huiwering kan die proses aanvanklik soms tydrowend, slordig en onduidelik voorkom. Hierdie aanvanklike waarnemings is sprekend van die sogenaamde chaordiese model (vgl. voetnoot 1$)$ - 'n veranderingsmodel wat diepgaande orde en verandering bewerkstellig (Gilbert 2004:51-58; Niemandt 2007:28, 29).

'n Verdere moontlike oorsaak vir die afwesigheid, of vir die stadige vordering in aanvaarding en aanwending van $\mathrm{WO}$, is in die gelowige self geleë (Hendriks 2003). Die tradisionele gelowige is in die hantering van problematiese situasies in gevestigde denksisteme vasgevang. Die tradisioneel veilige en heilige werkswyses waarbinne gelowiges knus gekluister leef (Hendriks 2003), versterk die dwaling dat geen denkverandering (vgl. onder andere Rom 12:2) of verbetering binne die kerkpraktyk nodig is nie. Schwarz (1999:7) beskryf gelowiges met só 'n uitgangspunt as 'beyond question' in die beskouing van hulle kerkpraktyk. Die onbewustheid van hierdie toestand by gelowiges verhinder hulle om wilsbesluite te neem wat deur geloofsmoed kan oorgaan tot ernstige besinning om die lig in die donkerte te laat skyn (Martin 2001:263, 264, 267-275; Van Helden 2010:371, 351, 364). 'n Aantal kritiese opmerkings binne die konteks van Schoeman en Van den Berg (2011:5) se artikel oor WO bied waardevolle stof vir verdere navorsing.

\section{Voordelig of nadelig?}

Die volgende sake kan as voordelig of nadelig beskou word. Dit is noodsaaklik dat die inisieerders en deelnemers aan die WO-proses besef dat toewyding deur die hele proses noodsaaklik is. Omdat dit tyd in beslag neem en soms deurmekaar blyk te wees, is dit nodig dat almal wat by die saak betrokke is, volhardend toegewyd moet bly. Die proses word gewoonlik nie eenmalig afgehandel nie en daarom kan die saak nie vinnig as afgehandel beskou word nie. Verbeterende situasies vereis dat die hele 4D-proses deurloop moet word (vgl. 'WO - 'n Waarderende Taalaanpak'), dat refleksie deurgevoer word en dat almal betrokke en bereid moet wees tot revisionering (Brouwer et al. 2007:56).

\section{Toeëiening van Waarderende Ondersoek}

Die vlak van WO-toeëiening en -aanwending binne die kerkpraktyk verskil van die vlak binne die akademiese terrein (English et al. 2003:84-88; vgl. ook Branson 2004:1-17; Cooperrider \& Whitney 2005:7-35). Binne die gemeentelike opset is die aanslag informeel en die bedoeling is nie om die proses as akademiese navorsing aan te bied nie, maar eerder as 'n proses wat op die gemeente se eie unieke manier deurgevoer moet word. Die leierskorps van die gemeente kan die proses self deurvoer, of hulle kan van ' $n$ fasiliteerder gebruik gemaak. Die fasiliteerder kan gedurende die hele proses behulpsaam wees, of slegs inleidend optree. Aangesien WO nie net ' $n$ metode is nie, maar ook ' $n$ proses, 'n gesindheid en 'n manier van lewe (vgl. Branson 2004:19), is dit nie altyd nodig om in 'n gemeente wat aan die WOmanier van doen gewoond is, aan te kondig dat die WOproses gevolg word nie. Wanneer gemeentelede bereid en gewillig is om deel van die WO-proses te wees, toon hulle self aan dat hulle vir verandering gereed is.

Diepgaande verandering volg 'n dieper roete as wat gewoonlik tradisioneel deur die liniêr probleemgesentreerde benadering vir probleemoplossing gevolg word (vgl. voetnoot 1; Branson 2004:22; Gilbert 2004:51-58). Gelowiges wat werklik diepgrondig wil bekeer en die lig wil najaag, eien WO makliker vir hulself toe, aangesien Christus (die Lig en die Waarheid) die Alfa en die Omega is om die lig binne donker situasies aan die soekende gelowiges te openbaar.

'n Voorbeeld van die WO-aanpak binne 'n gereformeerde gemeente: 'n Voorbeeld van die WO-aanpak in die praktyk word vervolgens kortliks bespreek (Van Helden 2010:539556; vgl. ook 2013b, 2013c). Die fasilitering het inleidend in die gemeente geskied, deurdat die fasiliteerder die proses tydens die eerste twee stappe van die $4 \mathrm{D}$-proses behartig het. Gewoonlik word die 4D-proses nie altyd binne die bestek van 'n paar uur afgehandel nie. Die laaste twee stappe is in hierdie gemeente op 'n later stadium, sonder dat die fasiliteerder teenwoordig was, deurgevoer. Die redes hiervoor was omdat dit vir die fasiliteerder tydsgewys nie moontlik was om weer teenwoordig te wees nie en die deelnemers was tydens die laaste twee stappe van die proses buitendien sélf aktief in die deurvoer van die proses besig wat die fasiliteerder dus oorbodig gemaak het.

Die eerste byeenkoms is gereël om die oorsake van krimpende gemeentes onder die kerkraad se aandag te bring, om klem op die Groot Opdrag te lê en om Christus as die groot omkeerder van omstandighede daarin te ken. Daarna het die kerkraadslede op 'n een-tot-een-basis met mekaar oor goeie sake gesels wat, ten spyte van die negatiewe, wél in die krimpende bediening beleef is. Daar is ook op die wense, begeertes of gebede gefokus van hoe die kerkraad die bediening graag sou wou beleef het. 
Die eerste twee dele van die 4D-siklus, naamlik die Ontdekaktiwiteit (Discover) en die Droom-aktiwiteit (Dream), is tydens hierdie byeenkoms deurgevoer. Dit is na aanleiding van vrae oor kerkkrimping en kerkgroei gedoen, deur byvoorbeeld te vra: Wat maak jou opgewonde in die kerk? Watter dinge is dit wat lewe aan die gemeente gee? Wat is dit wat lekker, suksesvol en goed is in die gemeente? Wat is dit wat die beste resultate gee? Watter oomblik en persone staan in die goeie ervarings van die gemeente uit? Wat was vir jou 'n ware hoogtepunt in die gemeentelewe? Wat motiveer en inspireer jou binne die kerk? Wat is dit in die kerk wat 'n positiewe effek op jou gehad het? Waar het jy iets gesien wat goed werk en regtig effektief is? Dink aan 'n spesifieke gebeure wat van die goeie in die gemeentelewe getuig en vertel jou gespreksgenote daarvan. Gee besonderhede van die betrokkenes, waar, wanneer en hoekom dit plaasgevind het en vertel wat die resultaat daarvan was.

Die groep het twee-twee na mekaar geluister. Tydens die gesprek is geweldig baie inligting (kennis) gehoor. Elkeen het daarna net twee van die sake wat deur die gesprek na vore gekom het, saaklik neerskryf en mondelings daaroor terugvoering gegee. Die kennispoel is op hierdie manier verbreed deurdat almal die verskeidenheid en ooreenstemmende insette kon hoor. Die fasiliteerder het dit volgens 'n agtpunt-raamwerk op die blaaibord aangeteken en gesistematiseer. Refleksie het na terugvoering getoon dat daar 'n lang lys goeie punte in die kerkpraktyk bestaan waaroor nooit gepraat word of nooit aan gewerk word nie.

Die volgende stap was om die deelnemers op die toekoms te rig (Droom-aktiwiteit). Die deelnemers moes mekaar van hulle wense, gebede of begeertes oor die krimpende tendens vertel. Daarna het elkeen die inligting wat hierdeur verkry is, kortliks neergeskryf en terugvoering gegee. Die fasiliteerder het ook hierdie inligting op die blaaibord neergeskryf.

Die vrae vir hierdie aktiwiteit was sodanig geformuleer dat die kerkraadslede hulself moes indink hoe die bediening kán wees, byvoorbeeld: Wat is jou visie, droom, gebed of doel vir hierdie gemeente? Waardeur kan jou gereformeerde identiteit in die gemeente nog meer na vore kom? Wat in die bediening sal jou trots laat voel? Wat sal hoop in die gemeente laat toeneem? Wat wil jy eintlik in hierdie gemeente sien, ervaar en beleef? Veronderstel jy gaan vir 'n tydperk weg van die gemeente af en in hierdie tydperk gebeur die dinge waaroor jy gedroom het: hoe sou jy die gemeente by jou terugkoms beskryf deur dit wat jy sien en ervaar? Refleksie na afloop van die gesprek het getoon dat daar wense en gebede oor die bediening was wat nooit uitgespreek is nie.

Die fasiliteerder het die magdom kennis op die blaaibord aan die hand van 'n agtpunt-raamwerk gesistematiseer. Tendense is sigbaar aangedui deur die frekwensie van wense of drome op die agtpunt-raamwerk aan te bring. Op hierdie hoogtepunt het die byeenkoms verdaag. Die laaste twee stappe van die $4 \mathrm{D}$-siklus moes tot die volgende geleentheid oorstaan.
Hierdie voorbeeld waar die WO-taalaanpak se eerste twee stappe aangewend is, het elke kerkraadslid betrek. 'n Atmosfeer van energie, opwinding, hoop en entoesiasme het geheers en die besef om aan die Groot Opdrag gehoorsaam te wees, het voorop gestaan.

Ongeveer vyf jaar na die afloop van hierdie byeenkoms, op 13 April 2014, is 'n gesprek met Z. Botes, 'n gemeentelid wat deel van die stuurspan vir die multikulturele bediening is, gevoer. Sy het genoem dat die gemeente in samewerking met omringende gemeentes 'n multi-kulturele bediening begin het. Alhoewel hierdie pad stadig en moeilik is, word dit voortdurend in gebed aan die Here opgedra en word Hy geprys vir die groei wat reeds daar is.

\section{Gevolgtrekking}

Die WO-aanpak word as 'n nuttige en effektiewe hulpmiddel beskou, veral vir godsdienstige groepe, aangesien die WO-proses die gedagtes op sake fokus wat goed, reg en prysenswaardig is soos die Skrif in Filippense 4:8 voorskryf. Die denkwyse is op dit wat lig (verbetering) bewerkstellig, gefokus. Die geskiedenis van WO en navorsing wat aan die hand van WO gedoen is, toon dat die waarderende aanpak wêreldwyd nie nét as 'n metodologie binne formele akademiese kringe gebruik word nie. WO word grootliks op 'n informele wyse effektief binne enige problematiese situasie, ook binne die kerkpraktyk, aangewend. Binne die omkerende gesindheid van gereformeerdes behoort almal wat oor diep verandering ernstig is, van die verfrissende nuwe moontlikhede bewus te wees wat gemeentelede sélf deur die aanwending van die WO-instrument kan ontdek. Die aanpak bied gelowiges die ruimte om sáám hulle ou natuur te kruisig, gehoorsame nuwe denke deur nuwe uitkomste te vestig en die omkeer van gedagtes, woorde en dade tot eer en verheerliking van God en sy koninkryk aan te wend.

\section{Erkenning Mededinge belange}

Die outeur verklaar hiermee dat sy geen finansiële of persoonlike verbintenis het met enige party wat haar nadelig of voordelig kon beïnvloed het in die skryf van hierdie artikel nie.

\section{Literatuurverwysings}

Acta, kyk Gereformeerde Kerke in Suid-Afrika.

Allen, W., 2007, Participatory Action Research, viewed 21 June 2008, from http:// learningforsustainability.net/research/action_research.php

Branson, M.L., 2004, Memories, hopes and conversations: Al and congregational change, Alban Institute, Virginia.

Brouwer, R., De Groot, K., De Roest, H., Sengers, E. \& Stoppels, S. (reds.), 2007, Levend liggaam: Dynamiek van christelijke geloofsgemeenschappen in Nederland, Kok, Kampen.

Brydon-Miller, M., Greenwood, D. \& Maguire, P., 2003, 'Why Action Research?' Action Research, 1:21. http://dx.doi.org/10.1177/14767503030011002

Burger, C., 1999, Gemeentes in die kragveld van die Gees oor die unieke identiteit, taak en bediening van die kerk van Christus, BUVTON, Stellenbosch. (Gemeente en bediening, 4).

Cameron, H., Bhatti, D., Duce, C., Sweeney, J. \& Watkins, C., 2010, Talking about God in practice:Theological Action Research and Practical Theology, SCM, London. 
Chaffee, P.C., 2005, Claiming the light: Appreciative inquiry and congregational transformation, viewed 04 August 2013, from www.congregationalresources.org

Chambers, R., 1997, Whose reality counts? Putting the first last, Intermediate Technology Publications, London. http://dx.doi.org/10.3362/9781780440453

Champion, D. \& Stowell, F.A., 2003, 'Validating Action Research field studies: PEARL', Systemic Practice and Action Research 16(1), 21-36. http://dx.doi. org/10.1023/A:1021928511690

Cooperrider, D.L. \& Whitney, D., 2005, Appreciative Inquiry - A positive revolution in change, Berrett-Koehler Press, San Fransisco.

Cooperrider, D.L., Whitney, D. \& Stavros, J., 2008, Appreciative Inquiry handbook for leaders of change, 2 nd edn., Crown Custom Publishing, Ohio.

Darling-Hammond, L. \& Snyder, J., 2000, 'Authentic assessment of teaching in context', Teaching and Teacher Education 16, 523-545. http://dx.doi.org/10.1016/S0742051X(00)00015-9

De Wet, F.W., 2006, 'Die aanwending van Rolf Zerfass se handelingswetenskaplike model in prakties-teologiese teorievorming - 'n gereformeerde perspektief', In die Skriflig 40(1), 57-87. http://dx.doi.org/10.4102/ids.v40i1.333

Dick, B., 1997, Action learning and action research, viewed 21 July 2008, from http:// www.scu.edu.au/schools/gcm/ar/arp/actlearn.html

Du Toit, B., 2000, God? Geloof in 'n postmoderne tyd, CLF-Uitgewers, Bloemfontein.

English, L.M., Fenwick, T.J. \& Parsons, J., 2003, 'An Appreciative Inquiry into the spiritual values of Christian higher education', Christian Higher Education 2(1), spiritual values of Christian higher education', Christia
71-88. http://dx.doi.org/10.1080/15363750302208

Ganzevoort, R.R., 2006, De hand van God en andere verhalen: Over veelkleurige vroomheid en botsende beelden, Meinema, Zoetermeer.

Gereformeerde Kerke in Suid-Afrika, 2012, Acta - Handelinge van die tweede algemene sinode te Potchefstroom op 04 Januarie 2012 en volgende dae, V \& R Drukkery, Pretoria.

Gilbert, D.E., 2004, “"Deep change" or "slow death"? A practical road guide for the highway of change: A learning manual for church boards', PhD thesis, Faculty of Theology, Western Theological Seminary, Michigan.

Greenwood, J. \& Levin, M., 1998, Introduction to Action Research: Social research for social change, Sage, London.

Heitink, G., 1999, Practical Theology history theory action domains: Manual for Practical Theology, trans. R. Bruinsma, Eerdmans, Cambridge.

Hendriks, H.J., 1999, 'Verwagting vir die nuwe millennium: Gaan Gereformeerde Kerke groei, kwyn of verdwyn?' Woord en Daad 13,17-19, Lente.

Hendriks, H.J., 2003, Die toekoms van die kerk, die kerk van die toekoms, besigtig 10 Mei 2010, vanaf http://academic.sun.ac.za/theology/Profiles/Profile_documents/ Prof_Jurgens_Hendriks_Intreerede.pdf

Heyns, L.M. \& Pieterse, H.J.C., 1990, Eerste treë in die Praktiese Teologie, Gnosis, Pretoria.

Magnusson, E.R., 2012, 'Extending story listening as a practice of communal formation at the Lake Orion Church of Christ', Thesis, School of Theology, Abilene Christian University, Abilene.

Martin, B., 2001, 'Transforming a local church congregation through action research', Educational Action Research 9(2), 261-278. http://dx.doi. org/10.1080/09650790100200152

McLaren, B.D., 2006, The secret message of Jesus, uncovering the truth that can change everything, Thomas Nelson, Nashville.

Moore, M., 2008, Appreciative inquiry: The why? The what? The how?', Practice Development in Health Care 7(4), 214-220. http://dx.doi.org/10.1002/pdh.270

Morris, O.D., 1983, 'A research director's perspective of the issue of the neglect of churches in voluntary Action Research', Review of Religious Research 24(4), 308-311. http://dx.doi.org/10.2307/3511008

Motteux, N., Binns, T., Nel, E. \& Rowntree, K., 1999, 'Empowerment for development: Taking participatory appraisal further in rural South Africa', Development in Practice 9(3), 261-273. http://dx.doi.org/10.1080/09614529953007
Nel, M., 2009, Congregational analysis revisited: Empirical approaches, viewed 10 May 2010, from http://www.scielo.org.za/scielo.php?pid=S025994222009000100033\&script=sci_arttext

Niemandt, N., 2007, Nuwe drome vir nuwe werklikhede, Lux Verbi.BM, Wellington.

Niemandt, N., 2013, Nuweleiers virnuwe werklikhede, Christelike Uitgewersmaatskappy, Vereeniging.

Osmer, R., 2008, Practical Theology: An introduction, Eerdmans, Grand Rapids.

Pieterse, H.J.C., 1993, Praktiese Teologie as kommunikatiewe handelingsteorie, RGNUitgewers, Pretoria.

Pieterse, H.J.C., 2010, 'Die noodsaak van metateoretiese aspekte rakende 'n hermeneutiese benadering tot die Praktiese Teologie', Unisa, Pretoria.

Reason, P. (ed.), 1994, Human inquiry as discipline and practice in participation in human Inquiry, Sage, London.

Retief, F.J., 2009, 'The contribution of Appreciative Inquiry on the attitudes of church members towards a change in strategic focus', MA dissertation, Department of Business Studies, Management College of Southern Africa (MANCOSA), Durban.

Roxburgh, A.J., 1997, The missionary congregation, leadership and liminality, Trinity Press International, Harrisburg.

Schoeman, K. \& Van den Berg, J.A., 2011, " $n$ Waardering vir die positiewe! Waarderende betrokkenheid as ' $n$ gemeentelike lens en ' $n$ pastorale lens', HTS Teologiese Studies 67(2), 1-7. http://dx.doi.org/10.4102/hts.v67i2.887

Schwarz, C.A., 1999, Paradigm shift in the church - How natural church development can transform theological thinking, ChurchSmart Resources, Emmelsbüll.

Smit, C.J. \& Vorster, J.M., 2000, 'Die GKSA en sy gereformeerde identiteit: Kan dit behou word in 'n postmoderne gemeenskap?' In die Skriflig 34(4), 515-533.

Smith, D.H., 1983, 'Churches are generally ignored in contemporary voluntary Action research: Causes and consequences', Review of Religious Research 24(4), 295-303. http://dx.doi.org/10.2307/3511006

Smith, T.W., 1984, 'A comment on David Horten Smith's article: Churches are generally ignored in contemporary voluntary action research', Review of Religious Research 26(2D), 190, 191.

Strong, P., 2007, Romans $12: 2$ as an important paradigm for transformation in a Christian: A practical theological study, PhD thesis, Faculty of Theology, North-West University, Potchefstroom Campus, Potchefstroom.

Van Gelder, C., 2009, The ministry of the missional church, Baker Books, Grand Rapids.

Van Helden, S., 2010, "n Hermeneuties-empiriese strategie rakende die verskynsel van kerkkrimping in tradisioneel Afrikaanse susterkerke in Suid-Afrika - 'n Praktiesteologiese studie', PhD-proefskrif, Fakulteit Teologie, Noordwes-Universiteit, Potchefstroomkampus, Potchefstroom.

Van Helden, S., 2013a, 'Institusionalisme - Springlewendig in die kwynende Afrikaanse gereformeerde kerkpraktyk', In die Skriflig/In Luce Verbi 47(1), 1-13.

Van Helden, S., 2013b, 'Kerkgroei', Aanbieding in Rustenburg, besigtig 18 Julie 2013, vanaf https://www.youtube.com/watch?v=uM6-SCTc8L0

Van Helden, S., 2013c, Waarderende Ondersoek in GK George, Verslag in besit van die kerkraad.

Van Helden, S., 2014, 'Aspekte van 'n omkeerproses', In die Skriflig/In Luce Verbi 48(1), $1-13$.

Wepener, C., 2005, 'Research rituals: On the use of participatory action research in liturgical studies', Praktiese teologie in Suid-Afrika 20(1), June, Summer, 110-128.

Whitney, D., 2010, 'Appreciative Inquiry: Creating spiritual resonance in the workplace', Journal of Management, Spirituality and Religion 7(1), 73-88. http:// dx.doi.org/10.1080/14766080903497656

Whitney, D., Trosten-Bloom, A., Cherney, J. \& Fry, R., 2004, Appreciative team building, iUniverse, New York.

Whyte, W.F. (ed.), 1991, 'Introduction' in Participatory Action research, Sage, London. 